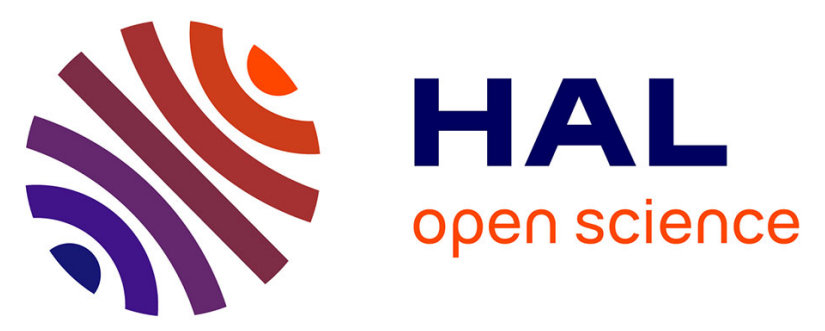

\title{
Organometallic Chemical Vapor Deposition of Palladium under Very Mild Conditions of Temperature in the Presence of a Low Reactive Gas Partial Pressure
} Jean-Cyrille Hierso, Christine Satto, Roselyne Feurer, Philippe Kalck

\section{- To cite this version: \\ Jean-Cyrille Hierso, Christine Satto, Roselyne Feurer, Philippe Kalck. Organometallic Chemical Vapor Deposition of Palladium under Very Mild Conditions of Temperature in the Presence of a Low Reactive Gas Partial Pressure. Chemistry of Materials, 1996, 8 (10), pp.2481-2485. 10.1021/cm960106m . hal- 02162951}

\section{HAL Id: hal-02162951 \\ https://hal.science/hal-02162951}

Submitted on 23 Jun 2019

HAL is a multi-disciplinary open access archive for the deposit and dissemination of scientific research documents, whether they are published or not. The documents may come from teaching and research institutions in France or abroad, or from public or private research centers.
L'archive ouverte pluridisciplinaire HAL, est destinée au dépôt et à la diffusion de documents scientifiques de niveau recherche, publiés ou non, émanant des établissements d'enseignement et de recherche français ou étrangers, des laboratoires publics ou privés. 


\title{
Organometallic Chemical Vapor Deposition of Palladium under Very Mild Conditions of Temperature in the Presence of a Low Reactive Gas Partial Pressure
}

\author{
J ean-Cyrille Hierso, ${ }^{\dagger}$ Christine Satto, ${ }^{\ddagger}$ Roselyne Feurer ${ }^{\ddagger}$ and Philippe Kalck ${ }^{*} \dagger$ \\ Laboratoire de Catalyse et Chimie Fine, Laboratoire de Cristallochimie, Réactivité et \\ Protection des Matériaux, URA-CNRS 445, Ecole Nationale Supérieure de Chimie de Toul ouse, \\ 118 route de Narbonne, 31077 Toul ouse cédex, France
}

Received February 6, 1996. Revised Manuscript Received May 16, $1996^{\otimes}$

\begin{abstract}
Palladium thin-film deposition was carried out from the known precursors $\mathrm{Pd}\left(\eta^{3}-\mathrm{C}_{3} \mathrm{H}_{5}\right)$ $(\mathrm{Cp})$, and $\mathrm{Pd}\left(\eta^{3}-\mathrm{C}_{3} \mathrm{H}_{5}\right)(\mathrm{hfa})$, where $\mathrm{Cp}$ is $\left(\eta^{5}-\mathrm{C}_{5} \mathrm{H}_{5}\right)$, cyclopentadienyl ligand and $\mathrm{hfa}$ is $\left(\mathrm{CF}_{3^{-}}\right.$ $\mathrm{COCHCOCF}_{3}$ ), hexafluoroacetylacetonato ligand. The use of a reactive gas such as dihydrogen led to unexpected low temperatures of deposition $\left(30-60^{\circ} \mathrm{C}\right)$. XPS and electron microprobe analyses revealed that low levels of carbon are incorporated to the palladium films. X-ray analyses showed crystalline deposits and scanning el ectron microscopy revealed grains of 300-1000 nm. Gas-phase analyses by mass spectrometry and GC/MS of deposition residues were realized to clarify the reaction mechanisms. Such a deposition process leads to metallic palladium with a good purity level.
\end{abstract}

\section{Introduction}

Organometallic chemical vapor deposition (OMCVD) takes a huge place among processes for generating thin films. ${ }^{1}$ Traditionally different materials can be deposited including semiconductors, ceramics, or noble metals, ${ }^{2}$ such thin films having several applications principally in electronics. However, OMCVD was shown to be a powerful method for generating highly dispersed catalysts. Indeed, recently our groups have reported 3,4 a new one-step method for producing rhodium-supported catalysts from suitable precursors. This process coupling OMCVD and a pulverulent support in a fluidized bed leads to obtain highly dispersed rhodium aggregates. The introduction of a partial pressure of dihydrogen assists the precursors decomposition and invol ves a completely different mechanistic pathway for deposition.

An approach of the reaction mechanisms occurring in the gas phase was given ${ }^{5}$ starting from $\mathrm{Rh}_{2} \mathrm{Cl}_{2}(\mathrm{CO})_{4}$. Temperatures of deposition, generally between 80 and $100{ }^{\circ} \mathrm{C}$, under a reduced gas pressure of $50-100$ Torr, can lead to small rhodium crystallites of good purity and great catalytic activity. ${ }^{4}$

These interesting results prompted us to extend this process to palladium and to establish the best experimental conditions to reach deposits of good quality as catalytic materials from suitable palladium precursors.

\footnotetext{
† Laboratoire de Catalyse et Chimie Fine.

₹ Laboratoire de Cristallochimie.

${ }^{\otimes}$ Abstract published in Advance ACS Abstracts, August 15, 1996.

(1) (a) Dupuis, R. D. Science 1984, 226, 623-629. (b) HampdenSmith, M. J .; Kodas, T. T. Chem. Vap. Deposition 1995, 1, 8 and references therein.

(2) For example see: (a) Gozum, J . E.; Pollina, D. M.; J ensen, J . A.; Girolami, G. S. J . Am. Chem. Soc. 1988, 110, 2688. (b) J ensen, J . A.; Gozum, J. E.; Pollina, D. M.; Girolami, G. S. J. Am. Chem. Soc 1988, 110, 1643. (c) Goto, T.; Vargas, R.; Hirai T. J. Phys. IV 1993, 3 , 297. (d) Bradley, D. C. Polyhedron 1994, 13, 111 and references therein.

(3) Feurer, R.; Reynes, A.; Serp, P.; Kalck, P.; Morancho, R. J .

Phys.IV 1995, 5, 1037.

(4) Serp, P.; Feurer, R.; Morancho, R.; Kalck, P.J . Mol. Catal. 1995, 101, 107.

(5) Serp, P.; Feurer, R.; Morancho, R.; Kalck, P.; Daran, J . C.; Vaisserman, J. J . Organomet. Chem. 1995, 498, 41.
}

The first attempts of noble metals deposition in the absence of a carrier gas gave films containing important amounts of carbon, chlorine, phosphorus, or other impurities. ${ }^{6}$ Another inconvenience was the poor adhesion of the CVD films and in addition the too-high temperatures required for deposition from some organometallic precursors. Several groups later reported excellent results using reactive carrier gas such as dihydrogen or dioxygen. 7,8

Noble-metal depositions using dihydrogen are mostly of good purity, allow significant temperature deposition decreases, and al so appear in some cases to improve the film adhesion.9c Different mechanistic studies were carried out concerning this phenomenon ${ }^{9}$ and are still an important investigation field. However, the dramatic reactivity of some compounds with dihydrogen when it is used as carrier gas or in a too-high partial pressure, leads the precursors to be decomposed before volatilization. ${ }^{8 c, 16}$

To avoid this drawback, it appears necessary to use a reactive gas with a very low partial pressure directly introduced in a close vicinity to the substrate.

The present paper reports the study of the deposition from two precursors, i.e., $\mathrm{Pd}\left(\eta^{3}-\mathrm{C}_{3} \mathrm{H}_{5}\right)(\mathrm{hfa})$, (hfa $=\mathrm{CF}_{3^{-}}$ $\left.\mathrm{COCHCOCF}_{3}\right)$, and $\mathrm{Pd}\left(\eta^{3}-\mathrm{C}_{3} \mathrm{H}_{5}\right)(\mathrm{Cp})\left(\mathrm{Cp}=\eta^{5}-\mathrm{C}_{5} \mathrm{H}_{5}\right)$, on planar glass substrates. It is shown that the addition of $1 \%$ of dihydrogen to the helium carrier gas allows us

(6) (a) Rand, M. J . J . Electrochem. Soc. 1973, 120, 686. (b) Rand M. J. J. Electrochem. Soc. 1975, 122, 811.

(7) (a) Chen, Y. J .; K aesz, H. D.; Thridandam, H.; Hicks, R. F. Appl. Phys. Lett. 1988, 53, 1591. (b) Xue, Z.; Strouse, M. J .; Shuh, D. K.; Knobler, C. B.; Kaesz, H. D.; Hicks, R. F.; Williams, R. S. J . Am. Chem. Soc. 1989, 111, 8779. (c) Kaesz, H. D.; Williams, R. S.; Hicks, R. F.; Zink, J . I.; Chen, Y. J .; Müller, H. J .; Xue, Z.; Xu, D.; Shuh, D. K.; Kim, Y. K. New J. Chem. 1990, 14, 527.

(8) (a) Kumar, R.; Rashidi, M.; Puddephatt R. J . Polyhedron 1989, 8, 551. (b) Kumar, R.; Rashidi, M.; Puddephatt R. J . Can. J . Chem 1991, 69, 108. (c) Yuan, Z.; Puddephatt R. J. Adv. Mater. 1994, 6, 51.

(9) (a) Dryden, N. H.; Kumar, R.; Ou, E.; Rashidi, M.; Roy, S Norton, P. R.; Puddephatt, R. J .; Scott, J. D. Chem. Mater. 1991, 3, 677 and references therein. (b) Puddephatt R. J. Polyhedron 1994, 13, 1233 and references therein. (c) Xue, Z.; Thridandam, H.; Kaesz, H. D.; Hicks, R. F. Chem. Mater. 1992, 4, 162. 


\section{Scheme 1. Representation of the CVD Apparatus}

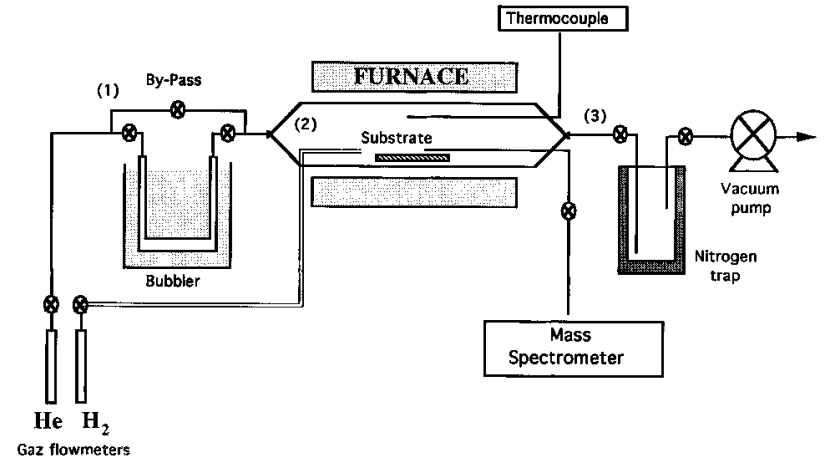

to control the deposition on the substrates between 30 and $60{ }^{\circ} \mathrm{C}$.

\section{Experimental Section}

All products were purchased from Aldrich Chemical Co. except for $\mathrm{PdCl}_{2}$ generously loaned by the Comptoir LyonAlemant-Louyot.

All precursors syntheses were carried out under nitrogen atmosphere using Schlenk techniques. The organometallic precursors were synthesized according to literature methods (with some modifications concerning $\mathrm{Pd}\left(\eta^{3}-\mathrm{C}_{3} \mathrm{H}_{5}\right)(\mathrm{hfa})$ ) and then purified by sublimation. ${ }^{10,11}$ Both of them can be stored several months under argon at $-18{ }^{\circ} \mathrm{C}$ and can be handled under air for short periods without any alteration.

Preparation of $\mathrm{Pd}\left(\eta^{3}-\mathrm{C}_{3} \mathrm{H}_{5}\right)(\mathrm{hfa})$ was carried out starting from a bis(allyl) di- $\mu$-chlorodipalladium(II) $(2 \mathrm{~g}, 5.5 \mathrm{mmol})$ suspension in $400 \mathrm{~mL}$ of diethyl ether.

To a stirred solution of sodium hydroxide $(0.64 \mathrm{~g}, 16 \mathrm{mmol})$ in $70 \mathrm{~mL}$ of water was added 1,1,1,5,5,5-hexafluoroacetylacetone $(3.1 \mathrm{~g}, 14.9 \mathrm{mmol})$. This latter solution was poured dropwise into the ether suspension of $\mathrm{Pd}_{2} \mathrm{Cl}_{2}\left(\eta^{3}-\mathrm{C}_{3} \mathrm{H}_{5}\right)_{2}$, and the mixture was stirred for $10 \mathrm{~min}$. The complex dissolved completely and the solution became yellow-green. The etheral layer was separated, dried over anhydrous magnesium sulfate, and filtered under nitrogen. The solvent was evaporated and the residue was purified by sublimation at $30-40{ }^{\circ} \mathrm{C}$ under reduced pressure (10-1 Torr). Bright yellow crystals were obtained in good yield (3.6 g, $10.2 \mathrm{mmol}, 93 \%)$.

Palladium thin films depositions were realized in a CVD apparatus as described in Scheme 1 (horizontal hot-wall reactor). The reactor (2) is a Pyrex tube of $11 \mathrm{~mm}$ internal diameter. The other different parts $(1,3)$ are steel made. Before each deposition the apparatus was cleaned out with detergent, deionized water, and acetone and then kept for 12 $\mathrm{h}$ under dynamic vacuum. The glass substrates were boiled in $40 \mathrm{~mL}$ of trichloroethane then in $40 \mathrm{~mL}$ of acetone and finally dried inside the reactor under an helium flow $(86 \mathrm{~mL} /$ min, pressure 50 Torr) for $1 \mathrm{~h}$. During this time the furnace and the ribbon heater were hel d to the required experimental temperatures. The helium carrier gas becomes saturated with vapors of the palladium precursors by passing upstream through a sinterred glass plate holding the solid organometallic complex. To fix the vapor pressure, all the sublimator system was maintained at a constant temperature by a regulated water bath. Dihydrogen was introduced near to the substrate to allow a better control of the deposition area. The Pyrex tube reactor was heated by an electric temperaturecontrolled furnace. An on-line mass spectrometer Balzers QMS was set up upon the deposition area via a capillary tube. Decomposition gases as well as the eventually unreacted precursors were trapped at liquid nitrogen temperature. Liquid residues were analyzed on a GC-MS Perkin-EImer Q

(10) Tatsuno, Y.; Yoshida, T.; Otsuka, S. Inorg. Synth. 1979, 19, 220.

(11) Imamura, S.; Kajimoto, T.; Kitano, Y.; Tsuji, J . Bull. Chem. Soc J pn. 1969, 42, 805.
Mass 910 . The palladium films were analyzed by X-ray photoelectron spectroscopy (XPS) to identify the surface species. XPS spectra were obtained by using a VG Escalab MK II with an unmonochromatized $\mathrm{MgK} \alpha \mathrm{X}$-ray source $(\lambda=0.989$ $\mathrm{nm}$ ) under a pressure of $6 \times 10^{-11} \mathrm{kPa}$. X-ray diffraction analyses were carried out on a Seifert XRD 3000 with the radiation $\mathrm{Cu} K \alpha(\lambda=0.15406 \mathrm{~nm})$. Qualitative and quantitative analyses were realized using an Electron Microprobe Cameca SX50. Analytical conditions were 15 or $10 \mathrm{kV}$ depending on the thickness of the film (to avoid support analyses) and $20 \mathrm{nA}$ for probe current. Palladium was analyzed on an L $\alpha$ emission line with a PET diffracting crystal. The carbon ratio was calculated by difference and not analyzed because of the interference between $\mathrm{C} \mathrm{K} \alpha$ and second-order $\mathrm{Pd} \mathrm{M} \gamma$ on multilayer $(\mathrm{Ni} / \mathrm{C}, 2 \mathrm{~d}=95 \AA$ ) diffracting crystal. The measurements have been carried out in various regions of the samples by comparison with a pure palladium thread as standard (99.9\% of purity).

\section{Results and Discussion}

A summary of previous works published on the OMCVD of the palladium precursors $\mathrm{Pd}\left(\eta^{3}-\mathrm{C}_{3} \mathrm{H}_{5}\right)(\mathrm{Cp})$ and $\mathrm{Pd}\left(\eta^{3}-\mathrm{C}_{3} \mathrm{H}_{5}\right)(\mathrm{hfa})$ is shown in Table 1 , our main results of low-temperature metallization are also given.

Deposition Process. The two precursors $\mathrm{Pd}\left(\eta^{3}\right.$ $\left.\mathrm{C}_{3} \mathrm{H}_{5}\right)(\mathrm{Cp})(\mathbf{1})$ and $\mathrm{Pd}\left(\eta^{3}-\mathrm{C}_{3} \mathrm{H}_{5}\right)(\mathrm{hfa})(\mathbf{2})$ were chosen due to both their satisfactory stability in air at room temperature and their high volatility. Provided no dihydrogen was introduced into the sublimation box, the complexes sublime without any decomposition. Temperatures of volatilization between 30 and $50{ }^{\circ} \mathrm{C}$ were maintained to reach a molar ratio of precursors in helium ranging between $1 \times 10^{-3}$ and $4 \times 10^{-3}$ at a 50 Torr total pressure (Table 2 ).

In the presence of helium only as carrier gas $(86 \mathrm{~mL} /$ min) under a pressure of 50 Torr, complex $\mathbf{1}$ began to decompose at $260{ }^{\circ} \mathrm{C}$. Above this temperature bright silvery adhesive coatings were obtained. Under the same experimental conditions no deposition of complex 2 was noted below $410{ }^{\circ} \mathrm{C}$. N oteworthy above $410{ }^{\circ} \mathrm{C}$ dark adhesive deposits were obtained, whose XPS semiquantitative analyses show an important carbon contamination. Thus without the incorporation of reactive gas our results were very similar to those reported by Girolami and Puddephatt (obtained under a $10^{-4}$ Torr vacuum without carrier gas). Nevertheless introducing dihydrogen as reactive gas in the precursor and helium vapor mixture ( $1 \% \mathrm{vol} / \mathrm{vol}, 0.8 \mathrm{~mL} / \mathrm{min}$ ) induced dramatic changes in the temperature deposition as well as in the quality of the deposits. Indeed chemical vapor depositions were performed at temperatures as low as $30{ }^{\circ} \mathrm{C}$ for $\mathbf{1}$ and $45^{\circ} \mathrm{C}$ for $\mathbf{2}$, bright metallic thin films being realized up to $60^{\circ} \mathrm{C}$, using complex $\mathbf{1}$ and gray metallic films using complex 2 . Above $60-70^{\circ} \mathrm{C}$ without any specific surface treatment of the substrate, deposition using $1 \%$ of dihydrogen produced wrinkled films which did not adhere to the substrate; a metallic powder was found on the substrate, due presumably to the decomposition of the precursors in the gas phase.

Characterization of the Deposits. X-ray photoelectron spectroscopy of deposits obtained from $\operatorname{Pd}\left(\eta^{3}\right.$ $\left.\mathrm{C}_{3} \mathrm{H}_{5}\right)(\mathrm{Cp})$ shows the $\mathrm{Pd} 3 \mathrm{~d}_{5 / 2}$ and the $\mathrm{Pd} 3 \mathrm{~d}_{3 / 2}$ peaks at respectively 335.7 and $340.9 \mathrm{eV}$ due to elemental palladium as displayed on the extension of Figure 1. We also note a $\mathrm{C} 1 \mathrm{~s}$ peak at $284.5 \mathrm{eV}$ due to graphitic carbon 
Table 1. Summary of Reported Results on CVD of Palladium from Precursors 1 and 2

\begin{tabular}{|c|c|c|c|c|c|c|c|}
\hline compound & $\begin{array}{c}\text { carrier gas/ } \\
\text { pressure (Torr) }\end{array}$ & $\begin{array}{l}\text { deposition } \\
\text { temp }\left({ }^{\circ} \mathrm{C}\right)\end{array}$ & impurities & $\begin{array}{c}\text { substrate } \\
\text { nature }\end{array}$ & $\begin{array}{l}\text { crystalline } \\
\text { state }\end{array}$ & $\begin{array}{l}\text { deposits } \\
\text { aspect }\end{array}$ & ref \\
\hline $\mathrm{Pd}\left(\eta^{3}-\mathrm{C}_{3} \mathrm{H}_{5}\right)(\mathrm{Cp})$ & vacuum $/ 10^{-4}$ & 250 & $5 \% \mathrm{C}$ & $\begin{array}{l}\text { glass } \\
\text { copper } \\
\text { steel } \\
\text { aluminum }\end{array}$ & amorphous & bright metallic & $2 a$ \\
\hline $\begin{array}{l}\mathrm{Pd}\left(\eta^{3}-\mathrm{C}_{3} \mathrm{H}_{5}\right)(\mathrm{Cp}) \\
\mathrm{Pd}\left(\eta^{3}-\mathrm{C}_{3} \mathrm{H}_{5}\right)(\mathrm{hfa}) \\
\mathrm{Pd}\left(\eta^{3}-\mathrm{C}_{3} \mathrm{H}_{5}\right)(\mathrm{hfa}) \\
\mathrm{Pd}\left(\eta^{3}-\mathrm{C}_{3} \mathrm{H}_{5}\right)(\mathrm{hfa}) \\
\mathrm{Pd}\left(\eta^{3}-\mathrm{C}_{3} \mathrm{H}_{5}\right)(\mathrm{hfa}) \\
\mathrm{Pd}\left(\eta^{3}-\mathrm{C}_{3} \mathrm{H}_{5}\right)(\mathrm{hfa})\end{array}$ & $\begin{array}{l}\mathrm{He} / 50^{\mathrm{a}} \\
\text { vacuum } / 10^{-4} \\
\mathrm{O}_{2} / 10^{-2} \\
\mathrm{H}_{2}+\mathrm{H}_{2} \mathrm{O} / 10^{-2} \\
\mathrm{H}_{2} / 5 \times 10^{-2} \\
\mathrm{He} / 50^{\mathrm{a}}\end{array}$ & $\begin{array}{r}30-60 \\
410 \\
330 \\
160 \\
140 \\
45-60\end{array}$ & $\begin{array}{l}<3 \% \mathrm{Cb}^{b} \\
22 \% \mathrm{C} \\
<1 \% \mathrm{C} \\
4 \% \mathrm{C} \\
15 \% \mathrm{C} \\
<1 \% \mathrm{C}^{b}\end{array}$ & $\begin{array}{l}\text { glass } \\
\text { glass } \\
\text { glass } \\
\text { glass } \\
\text { glass } \\
\text { glass }\end{array}$ & $\begin{array}{l}\text { crystalline } \\
\text { crystalline } \\
\text { crystalline } \\
\text { microcrystalline } \\
\text { crystalline }\end{array}$ & $\begin{array}{l}\text { bright metallic } \\
\text { shiny gray } \\
\text { metallic } \\
\text { metallic } \\
\text { metallic } \\
\text { gray metallic }\end{array}$ & $\begin{array}{l}\text { this work } \\
8 c \\
8 c \\
8 c \\
8 c \\
\text { this work }\end{array}$ \\
\hline
\end{tabular}

a $1 \%$ of $\mathrm{H}_{2}$ is introduced as reactive gas. ${ }^{b}$ Weight percent. For other deposition works on $\mathrm{Pd}\left(\eta^{3}-\mathrm{C}_{3} \mathrm{H}_{5}\right)(\mathrm{Cp})$ see refs $12-15$.

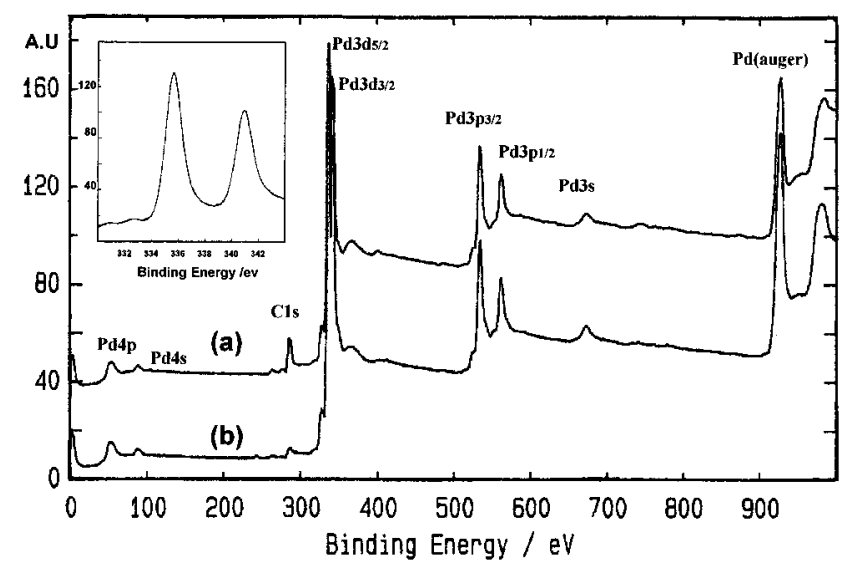

Figure 1. XPS spectra of a palladium deposit: (a) deposit as obtained after an OMCVD experiment from $\mathrm{Pd}\left(\eta^{3}-\mathrm{C}_{3} \mathrm{H}_{5}\right)(\mathrm{Cp})$ at $45^{\circ} \mathrm{C}$; (b) after $10 \mathrm{~min}$ of etching with $\mathrm{Ar}^{+}$ions. Extension of the two $P d 3 d_{3 / 2}$ and $P d 3 d_{5 / 2}$ signals is shown on the left.

Table 2. Molar Ratio of the Precursors Used in the CVD Experiments at a $\mathbf{5 0}$ Torr Total Pressure

\begin{tabular}{llll}
\hline $\mathrm{Pd}\left(\eta^{3}-\mathrm{C}_{3} \mathrm{H}_{5}\right)(\mathrm{Cp})$ & & \\
$\quad$ uublimation temp $\left({ }^{\circ} \mathrm{C}\right)$ & 30 & 35 & 40 \\
$\quad$ molar ratio & $1.15 \times 10^{-3}$ & $1.99 \times 10^{-3}$ & $3.34 \times 10^{-3}$ \\
$\mathrm{Pd}\left(\eta^{3}-\mathrm{C}_{3} \mathrm{H}_{5}\right)(\mathrm{hfa})$ & & & \\
$\quad$ uublimation temp $\left({ }^{\circ} \mathrm{C}\right)$ & 40 & 45 & 50 \\
$\quad$ molar ratio & $1.10 \times 10^{-3}$ & $1.56 \times 10^{-3}$ & $2.19 \times 10^{-3}$
\end{tabular}

or organic fragments such as $\mathrm{C}(\mathrm{H}) \mathrm{n} .{ }^{17}$ A 10 min etching with argon ions decreased significantly the amount of carbon on the film surface. XPS spectra of deposits obtained from $\mathrm{Pd}\left(\eta^{3}-\mathrm{C}_{3} \mathrm{H}_{5}\right)$ (hfa) show the same characteristic peaks due to elemental palladium and carbon (Figure 2). In addition two peaks at 688.1 and $600 \mathrm{eV}$ both due to some fluorine surface contaminants and an Auger peak at $745 \mathrm{eV}$ due to oxygen surface contamination are revealed. After etching the films with argon ions during $10 \mathrm{~min}$, the three peaks due to fluorine and oxygen disappear while the carbon signal decreases significantly. No palladium oxide is noted indicating the clean separation of the hexafluoroacetylacetonato ligand from the metal.

(12) For other works on $\mathrm{Pd}\left(\eta^{3}-\mathrm{C}_{3} \mathrm{H}_{5}\right)(\mathrm{Cp})$ see: Feurer, E.; Suhr, H. Thin Solid Films 1988, 157, 81.

(13) Stauf, G. T.; Dowben, P. A.Thin Solid Films 1988, 156, L 31.

(14) Thomas, R. R.; Park, J . M. J . Electrochem. Soc. 1989, 136, 1661.

(15) (a) Dossi, C.; Bartsch, A.; Losi, P. Adv. Synth. Methodol. Inorg. Chem. 1991, 83. (b) Dossi, C.; Psaro, R.; U go, R.; Zhang C. Z.; Sachtler W. M. H. J . Catal. 1994, 149, 92.

(16) Yuan, Z.; J iang, D.; Naftel, S. J .; Sham, T.-K.; Puddephatt R. J. Chem. Mater. 1994, 6, 2151.

(17) Handbook of X-ray Photoel ectron Spectroscopy; Perkin-EImer Corp., 1992.

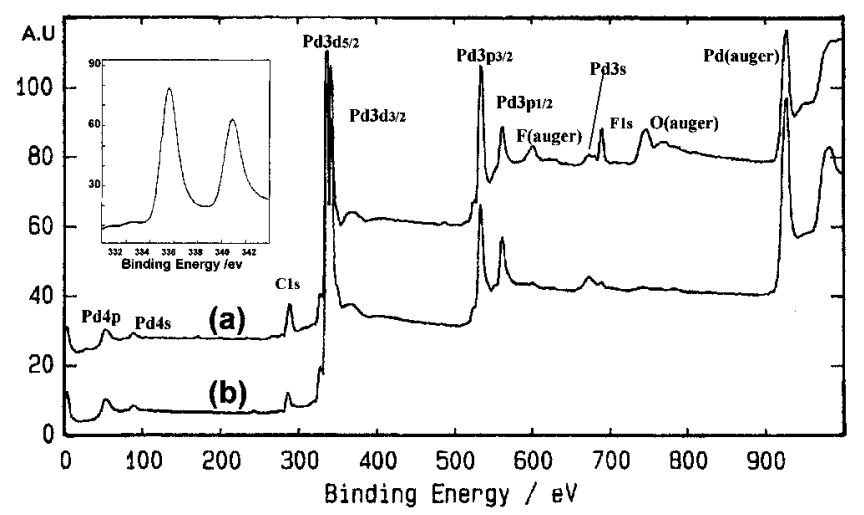

Figure 2. XPS spectra of a palladium deposit: (a) deposit as obtained after an OMCVD experiment from $\mathrm{Pd}\left(\eta^{3}-\mathrm{C}_{3} \mathrm{H}_{5}\right)(\mathrm{hfa})$ at $35^{\circ} \mathrm{C}$; (b) after $10 \mathrm{~min}$ etching with $\mathrm{Ar}^{+}$ions. Extension of the two $\mathrm{Pd}_{3} \mathrm{~d}_{3 / 2}$ and $\mathrm{Pd} 3 \mathrm{~d}_{5 / 2}$ signals is shown on the left.

Preliminary qualitative el ectron microprobe experiments of etched deposits from $\mathbf{1}$ have shown contamination by carbon. From $\mathbf{2}$ no contamination by fluorine and a very few carbon amounts were noted; a very weak signal revealing oxygen atoms at a trace level was detected by careful scanning on multilayer $(\mathrm{W} / \mathrm{Si}, 2 \mathrm{~d}=$ $60 \AA$ ) diffracting crystal. Quantitative analyses have revealed that whatever the deposition temperature between 30 and $60{ }^{\circ} \mathrm{C}$ for $\mathrm{Pd}\left(\eta^{3}-\mathrm{C}_{3} \mathrm{H}_{5}\right)(\mathrm{Cp})$ the purity ranges between 97 and $100 \%$, the level of carbon contamination being thus less than 3\% (weight/weight). Starting from $\mathrm{Pd}\left(\eta^{3}-\mathrm{C}_{3} \mathrm{H}_{5}\right)(\mathrm{hfa})$, the thin-film purity is more than $99 \%$ for deposition temperatures between 45 and $60{ }^{\circ} \mathrm{C}$.

As previously noted by several authors, the presence of the cyclopentadienyl ligand seems to induce a more important carbon contamination. No fluorine contamination from the hexafluoroacetylacetonato ligand was noted, which is an important result regarding the activity of future catalytic materials.

$X$-ray diffraction studies of metallic films grown at low temperature (Figure 3) showed the characteristic spectra of crystalline palladium, without any particular orientation.

Scanning electron microscopy showed that Pd films contain grains having a size between 300 and $1000 \mathrm{~nm}$ depending on temperature and time of deposition (Figure 4).

Mechanistic Considerations. To approach the decomposition mechanism of the two palladium complexes, on-line measurements by mass spectrometry were carried out along the experiments.

All the organic species present in the gas phase have been identified by their fragmentation pattern, i.e., 


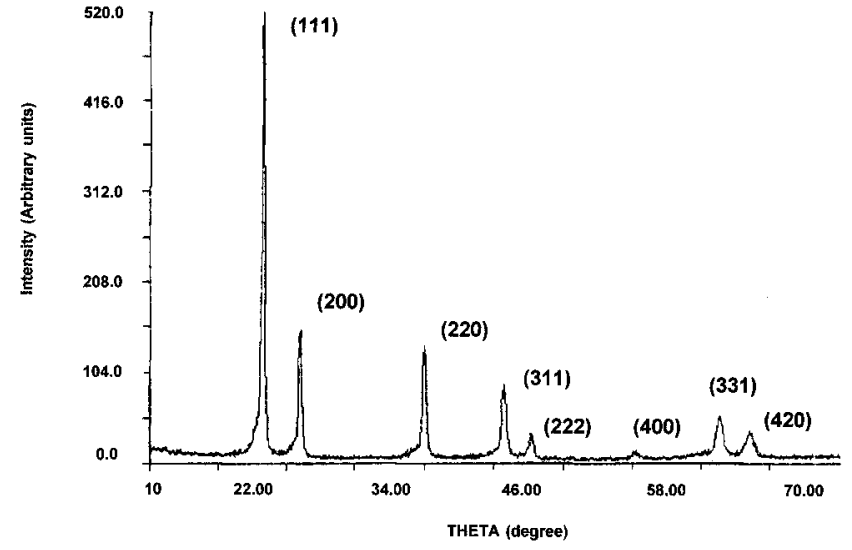

Figure 3. X-ray diffraction pattern of a Pd film from 2 at 60 ${ }^{\circ} \mathrm{C}$.
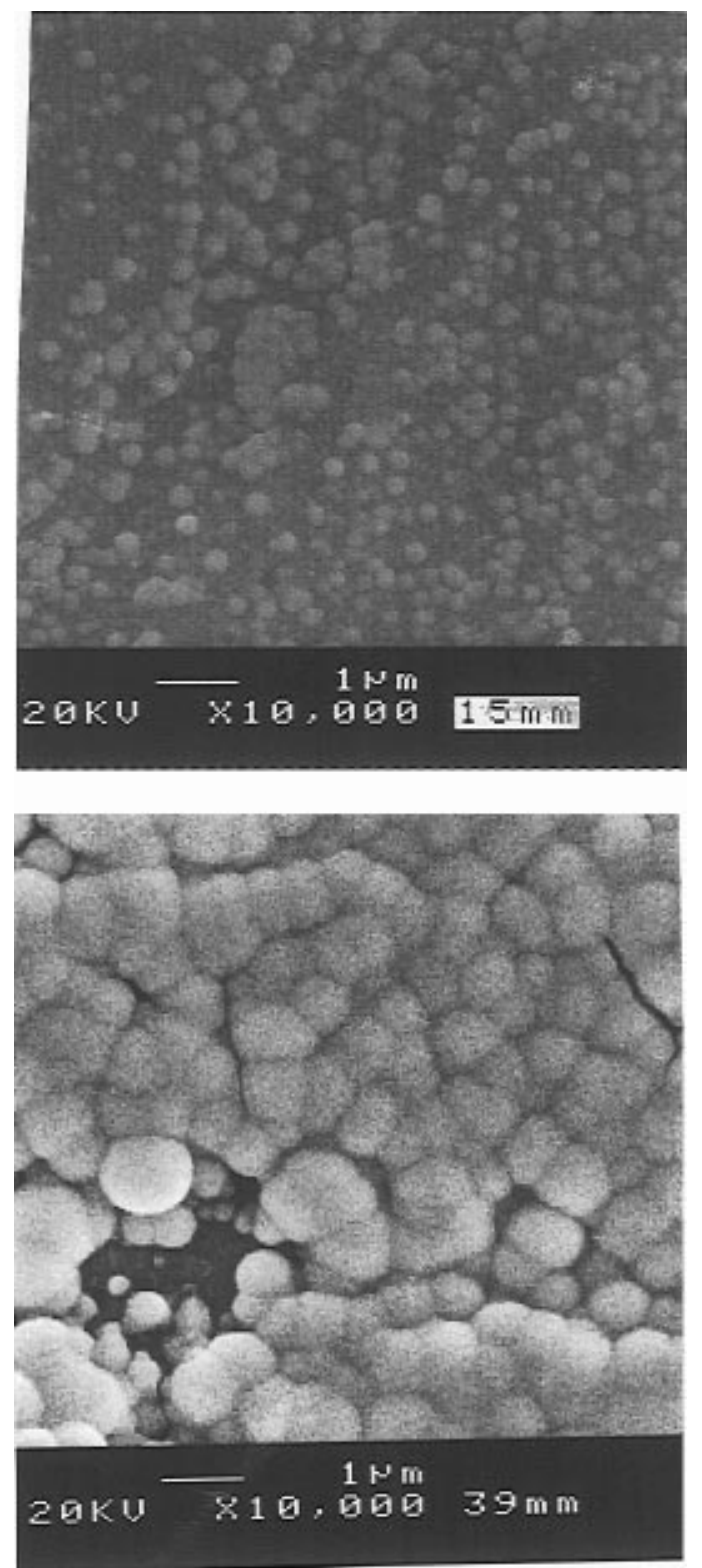

Figure 4. Scanning electron microscope (SEM) photographs of the Pd film from $\mathbf{1}$ at $35^{\circ} \mathrm{C}$ (a, top) and $80{ }^{\circ} \mathrm{C}$ (b, bottom).

concerning $\mathrm{Pd}\left(\eta^{3}-\mathrm{C}_{3} \mathrm{H}_{5}\right)(\mathrm{Cp})$ : cyclopentadiene, cyclopentene, cyclopentane, propane, and presumably propene (with an incertainty due to the overlaps of all its fragments with those of propane and cyclopentane).

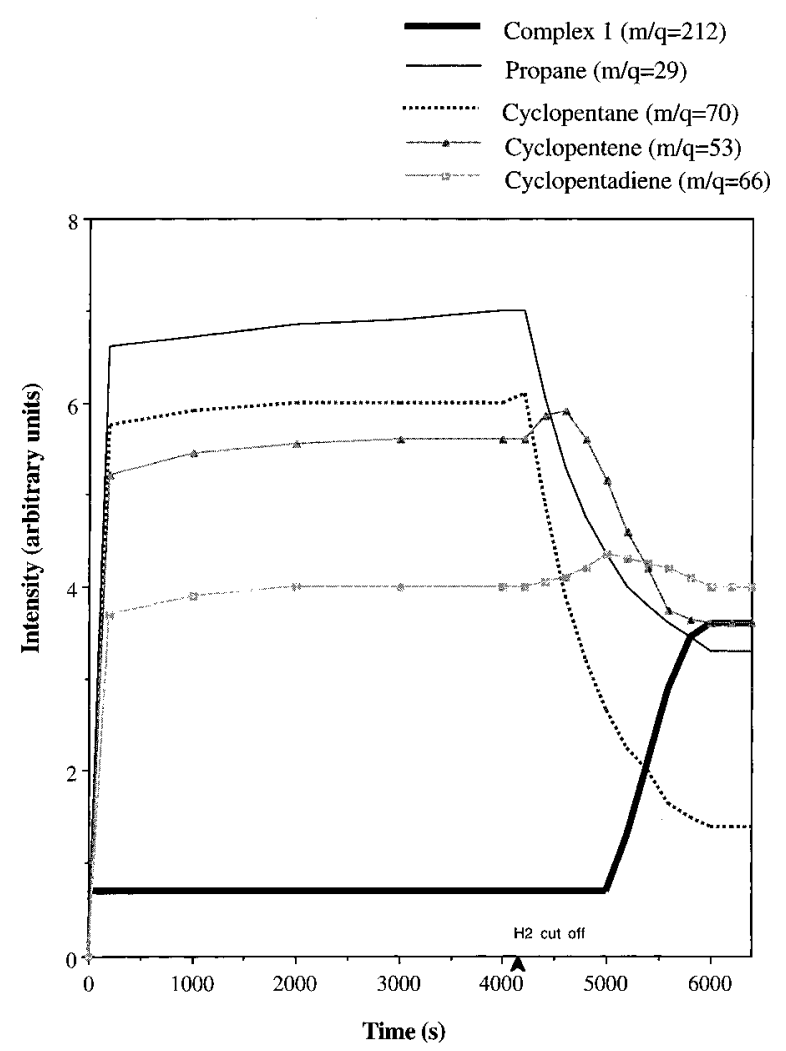

Figure 5. Gas-phase evolution during $\mathrm{Pd}\left(\eta^{3}-\mathrm{C}_{3} \mathrm{H}_{5}\right)(\mathrm{Cp})$ deposition in the presence of $\mathrm{H}_{2}$. The substrate temperature was $35^{\circ} \mathrm{C}$; Hydrogen flow was cut off after $4200 \mathrm{~s}$.

The GC/MS identification of the trapped residues attests to the formation of cyclopentene. To foll ow the modifications occuring in the gas-phase composition the characteristic fragments at $\mathrm{m} / \mathrm{q}=212$ and 147 for precursor $1, \mathrm{~m} / \mathrm{q}=66$ for cyclopentadiene, $\mathrm{m} / \mathrm{q}=68$ and 53 for cyclopentene, $\mathrm{m} / \mathrm{q}=70$ and 55 for cyclopentane and $\mathrm{m} / \mathrm{q}=29$ for propane were retained. Thermolysis of $\mathrm{Pd}\left(\eta^{3}-\mathrm{C}_{3} \mathrm{H}_{5}\right)(\mathrm{Cp})$ precursor in the absence of any reactive gas was reported to give a mixture of propene, cyclopentadiene, and traces of hexadiene, consistent with mainly a radical mechanism. ${ }^{2 a}$ In our conditions, introduction of dihydrogen leads rather to concerted mechanisms with hydrogenation of the original palladium ligands.

Indeed, in a blank experiment a vapor phase containing cycl opentadiene mixed with dihydrogen (ratio of $\mathrm{H}_{2}$ / cyclopentadiene 1/100) was introduced upon a naked glass substrate at $45^{\circ} \mathrm{C}$; no transformation of the olefin was noted. The same experiment under the same conditions but with a palladium film deposited on the glass substrate surface showed the immediate formation of cyclopentene and cyclopentane, in agreement with a concerted heterogeneous hydrogenation mechanism. A classical OMCVD experiment was carried out in the previously determined conditions: under 50 Torr of total pressure (with $3 \%$ of $\mathrm{H}_{2}$ in helium) at $35{ }^{\circ} \mathrm{C}$; the evolution of the concentration of the various gaseous species is displayed in Figure 5 . After the system reached steady-state conditions, whereas palladium deposition occurred the gas phase was shown to contain low amounts of $\mathrm{Pd}\left(\eta^{3}-\mathrm{C}_{3} \mathrm{H}_{5}\right)(\mathrm{Cp})$, and the hydrogenated ligands, i.e., cyclopentadiene, cyclopentene, cyclopentane, and propane. At a given time (ca, $70 \mathrm{~min}$ ) the admission of dihydrogen was cut off, the other conditions being maintained constant. An immediate decrease of 
alkanes was noted, whereas the concentrations of cyclopentadiene and especially cyclopentene increased. As long as hydrogen was present on the palladium surface the $\mathrm{Pd}\left(\eta^{3}-\mathrm{C}_{3} \mathrm{H}_{5}\right)(\mathrm{Cp})$ still decomposed at the same rate for about $15 \mathrm{~min}$. After this period, hydrogen on the surface was presumably totally consumed: the concentration of precursor in the gas phase increased, but the deposition proceeded further since, except for cyclopentane, all the products of decomposition were still detected at significant levels.

Thus, the mechanism appears to be autocatalytic since a temperature of decomposition near $400{ }^{\circ} \mathrm{C}$ is normally expected for decomposition without dihydrogen as reactive gas. From these findings we can conclude that the low-temperature deposition of $\mathrm{Pd}\left(\eta^{3}\right.$ $\left.\mathrm{C}_{3} \mathrm{H}_{5}\right)(\mathrm{Cp})$ occurs mainly on the surface and involves adsorbed species easily hydrogenated and removed from the medium. The incorporation of only low amounts of graphitic carbon at temperatures around $45{ }^{\circ} \mathrm{C}$ is consistent with this surface mechanism. Complete kinetic studies of organometallic complexes hydrogenation catalyzed by platinum black were realized by Miller and Whitesides; 18 our observations with palladium films appear relatively close to their results on platinum studies. Noteworthy, as soon as dihydrogen is introduced, the deposition begins without any induction period contrary to some other reported experiments involving platinum ${ }^{9 \mathrm{c}}$ or rhodium complexes. ${ }^{3}$

Similarly the gas phase resulting from $\mathrm{Pd}\left(\eta^{3}-\mathrm{C}_{3} \mathrm{H}_{5}\right)$ (hfa) deposition was analyzed. On-line mass spectrometry measurements revealed the presence of trifluoropropanone, propane, and some hexafluoro-2,4-pentanedione. From the trap, GC/MS spectra confirmed the presence of trifluoropropanone and propane; an unreferenced compound ${ }^{19}$ was also detected, showing fragments at $\mathrm{m} / \mathrm{q}=142,141,123,113,99,95,69,51$, and 43. The same fragmentation pattern was also observed in the gas-phase analyses during OMCVD experiments.

(18) (a) Miller, T. M.; Izumi, A. N.; Shih, Y.-S.; Whitesides, G. M. J . Am. Chem. Soc. 1988, 110, 3146. (b) Miller, T. M.; McCarthy, T. J .; Whitesides, G. M. J . Am. Chem. Soc. 1988, 110, 3156. (c) Miller, T. M.; Whitesides, G. M. J . Am. Chem. Soc. 1988, 110, 3164.

(19) Mass spectra database NIST/EPA/NIH, version 4.1.; PerkinElmer Corp., 1992.
As previously detected for $\mathrm{Pd}\left(\eta^{3}-\mathrm{C}_{3} \mathrm{H}_{5}\right)(\mathrm{Cp})$ the allyl ligand is mainly hydrogenated in propane. However, the hfa ligand follows a different pathway. A part of the acetylacetonato ligand is hydrogenated, and a part is split into trifluoropropanone. A carbon-carbon bond can be cleaved giving presumably a trifluoroacetyl fragment and a [ $\left.\mathrm{CF}_{3} \mathrm{COCH}{ }^{*}\right]$ fragment which is hydrogenated. Trifluoroethanol has not been detected. However, the fragmentation pattern observed in GC/MS could be consistent with the compound $\mathrm{CF}_{3} \mathrm{CH}(\mathrm{OH}) \mathrm{CH}_{2}-$ $\mathrm{CHO}$. Except the peak at $\mathrm{m} / \mathrm{q}=51$ all the main peaks can be assigned: $\mathrm{m} / \mathrm{q}=142,\left[\mathrm{CF}_{3} \mathrm{CH}(\mathrm{OH}) \mathrm{CH}_{2} \mathrm{CHO}\right.$; $141, \mathrm{CF}_{3} \mathrm{CH}(\mathrm{OH}) \mathrm{CH}_{2} \mathrm{CO} ; 123$, [ $\mathrm{CF}_{3} \mathrm{CCH}_{2} \mathrm{CO}$ ]; 113 , [ $\mathrm{CF}_{3-}$ $\left.\mathrm{CH}(\mathrm{OH}) \mathrm{CH}_{2}\right] ; 99,\left[\mathrm{CF}_{3} \mathrm{CH}(\mathrm{OH})\right] ; 95,\left[\mathrm{CF}_{3} \mathrm{CCH}_{2}\right] ; 69$, $\left[\mathrm{CF}_{3}\right] ; 43,\left[\mathrm{CH}_{2} \mathrm{CHO}\right]$.

$\mathrm{CHF}_{3}$ has not been detected either by trapping or during on-line mass spectrometry experiments.

\section{Conclusion}

Two palladium complexes, $\mathrm{Pd}\left(\eta^{3}-\mathrm{C}_{3} \mathrm{H}_{5}\right)(\mathrm{Cp})$ and $\mathrm{Pd}-$ $\left(\eta^{3}-\mathrm{C}_{3} \mathrm{H}_{5}\right)(\mathrm{hfa})$, appear to be suitable precursors for a very low temperature chemical vapor deposition process provided small amounts of dihydrogen as reactive gas are introduced in the vapor phase just before the substrate. Analyses have shown that palladium is deposited between 30 and $60^{\circ} \mathrm{C}$ at a good purity level. These conditions are particularly well adapted to the OMCVD process in fluidized bed as found for the case of rhodium. ${ }^{3,4}$ Small sized particles are expected to be prepared in a single-step procedure as active heterogeneous catalysts.

Acknowledgment. This work was supported by the Conseil Scientifique de I'I nstitut National Polytechnique (BQR action). J.-C.H. thanks the "Ministère de I'Enseignement Supérieur et de la Recherche" for his research grant. We thank $A$. Reynes for assistance with mass spectrometry, and M. Provincial and G. Chatainier for XPS spectra. We are also grateful to P. de Parseval and the Service de Microsonde Electronique de I'U niversité Paul Sabatier de Toulouse for access to the Electron microprobe analyses apparatus.

CM960106M 